\title{
ESQUERDA E DIREITA SE ENCONTRAM NAS PÁGINAS DA REVISTA LEFT AND RIGHT: A JOURNAL OF THE LIBERTARIAN THOUGHT
}

\author{
Left and Right meet on the pages of the periodical \\ Left and Right: A journal of the libertarian thought
}

\section{Vinícius Patrocínio Pereira Costa*}

\begin{abstract}
Resumo: O presente trabalho pretende analisar como e porque a direita libertária dos EUA, que é um dos setores representantes do conservadorismo do pós-guerra - um movimento defensor dos preceitos do Estado enxuto e não intervencionista, do livre mercado e da soberania do indivíduo perante o coletivo - lançou uma tentativa de aliança com os grupos da Nova Esquerda (movimento negro, feminista, estudantil, entre outros) dos anos 60. Para isso será analisado a principal publicação libertária responsável por consolidar esta união, a revista Left and Right: A Journal of the Libertarian Thought. Argumenta-se que as transformações sofridas dentro do conservadorismo do pós-45 bem como a atmosfera política e cultural dos anos 60 , foram os principais responsáveis para que ambos os grupos buscassem desenvolver uma atuação política conjunta.

Palavras-chave: Libertarianismo, Direita, Esquerda, Estados Unidos
\end{abstract}

\begin{abstract}
This paper aims to analyze how and why the US libertarian right, one of the strains of postwar conservatism, and a movement that advocates the precepts of the lean and non-interventionist State, the free market, and the sovereignty of the individual before the collective, launched an alliance with the New Left groups (Black movement, Feminism, Student movement among others) of the 1960s. We intend to analyze the main libertarian publication responsible for consolidating this union, the magazine Left and Right: A Journal of the Libertarian Thought. It is argued that the transformations undergone within the post- 45 conservatism as well as the political and cultural atmosphere of the 60's, were the main factors responsible for both groups find a common ground on political action.
\end{abstract}

Keywords: Libertarianism, Right, Left.

Nas eleições presidenciais de 2016 o candidato do Partido Libertário Gary Johnson afirmou, em entrevista ao Washington Journal, que concorda com cerca de $73 \%$ das pautas defendidas por seu adversário político, o também presidenciável e socialista democrático, Senador Bernie Sanders. De acordo com Johnson, ele concorda com

o lado de Bernie que tem a ver com a liberdade de escolha, com um casamento igualitário para todos, (...) [que quer] acabar com as intervenções militares, que existe um capitalismo corporativo $^{1}$, que o governo realmente não é justo quando se trata do fornecimento de condições mais igualitárias, apoiar a legalização da maconha (apud BYRNES, 2016)

\footnotetext{
* História. Universidade Federal do Estado do Rio de Janeiro (UNIRIO). E-mail: patrocinio97@gmail.com ORCID: http://orcid.org/0000-0003-0456-9352

${ }^{1}$ Crony capitalism na fala original. A expressão diz respeito a um capitalismo marcado por relações duvidosas entre empresários e o aparelho estatal.
} 
Os jornais disseram que a fala do candidato seria uma tentativa deste de se aproximar de um eleitorado mais jovem e progressista, que naquele momento estava orbitando em torno da figura de Bernie Sanders.

Contudo, esta não foi a primeira vez que os libertários tentaram se aproximar da esquerda de alguma forma. Nos anos 60 eles também fizeram algo parecido, se valendo de uma retórica semelhante àquela expressa por Johnson. Enfatizando a defesa das liberdades individuais, o fim das intervenções militares dos EUA no estrangeiro e os problemas do Establishment corporativo, na tentativa de trazer a Nova Esquerda ${ }^{2}$ para dentro do libertarianismo.

Mas, por que tentar pôr em prática tal aliança? já que desde os anos 30 a defesa do livre mercado e da não interferência do Estado na sociedade, são os argumentos que pautaram o discurso da direita libertária. Tanto que nos anos 50 a revista The Freeman, um dos principais veículos de mídia do libertarianismo, publicou um editorial chamado "The Extreme Right" afirmando que a linha editorial da revista era:

The FREEMAN é dedicado à proposição de que a sociedade humana floresce melhor sob uma condição, liberdade. Nós somos a favor da liberdade, cem por cento, sem desconto. O que queremos dizer com a liberdade é bastante simples: é direito do indivíduo desenvolver o seu destino, seja qual for a habilidade que ele possui, sem interferência de governo, além do necessário para impedi-lo de interferir na liberdade dos outros. Nós estamos convencidos de que a liberdade é inerente ao indivíduo, um presente de Deus, e que a função do governo, a única função pela qual ele deve ser responsável, é proteger o indivíduo no gozo dessa investidura. Se for além desse campo, se invadir qualquer outra área da atividade humana, [ele] necessariamente, transgride a liberdade de algumas ou de todas as pessoas. Portanto, a liberdade funciona melhor quando o governo é pequeno, agindo sob poderes claramente delimitados, e está sujeito a vigilância constante. (THE FREEMAN, 1954, p.83)

Neste editorial o periódico também define o que entende por esquerda e centro

aqueles que estão à "esquerda" se opõem à liberdade, em variados graus. Os que estão três quartos para a "direita", advogam a redução da liberdade, ou a intervenção governamental, em aproximadamente um quarto da área de atividade humana; o "Centro," por definição, propõe que o governo ponha a mão em cerca de cinquenta por cento dos assuntos privados; enquanto a "extrema esquerda" deve ser a favor da abolição de toda a liberdade e condicionar escravidão sob o julgo do governo. (THE FREEMAN, 1954, p.83)

Ou seja, dentro da perspectiva libertária dos anos 50 a esquerda significa justamente o oposto de tudo que o libertarianismo defende, e qualquer tentativa de reconciliação entre os extremos acabaria no centro, o que para o The Freeman significa interferência em metade de toda e qualquer atividade humana. Diante disso, o editorial deixa claro que esquerda e direita não são apenas opostos, mas também, irreconciliáveis.

Este trabalho tem por objetivo entender como e porque o libertarianismo um dos três segmentos da direita conservadora do pós-guerra (NASH, 2006) ${ }^{3}$ - buscou se aliar com os grupos

\footnotetext{
2 Dentro do vocabulário político estadunidense é comum se falar de duas esquerdas. Se utilizando o termo Velho Esquerdo para designar marxistas, trotskistas e anarquistas dos anos 30, e de uma Nova Esquerda que emergirá nos anos 60 para se referir aos movimentos negros, feministas, estudantis entre outros.

${ }^{3}$ Aqui se entenderá o conservadorismo de acordo com a sua classificação clássica já consolidada na historiografia estadunidense. Seguindo o entendimento proposto por George Nash, que analisa o conservadorismo do pós-guerra como uma coalizão de forças de entre três seguimentos. São eles Libertarianismo, Tradicionalismo e Anticomunismo, cada uma dessas vertentes contribuiu para o fenômeno intelectual e 
representantes do novo esquerdismo da década de 1960. Tendo em mente que nos anos 50 tal aliança não parecia ser apenas improvável, mas também impossível.

\section{Os libertários e o movimento conservador}

A história do libertarianismo remonta ao momento do New Deal e o pós-guerra. Época esta em que os ideais pró-mercado defendido pelos libertários estavam em decadência, devido ao forte impacto causado pela Grande Depressão no mundo capitalista dos anos 20 e 30, colocando em descrédito o liberalismo laissez-faire ${ }^{4}$ (praticado desde o século XIX), levando muitos de seus defensores ao ostracismo político (BURGIN, 2009, p.4). Para dificultar ainda mais a situação dos apoiadores de mercados livres, a resposta encontrada pelos EUA para sair da crise havia sido as bem sucedidas medidas de regulação econômica e investimento social trazidas pelo New Deal, que auxiliaram na recuperação da economia norte-americana, e lançaram as bases para consolidação no pósguerra do famoso Estado Bem-Estar social norte-americano (LIMONCIC, 2009, p.32)

Ademais, os EUA não eram os únicos que adotaram o caminho do planejamento econômico estatal para sair da Depressão. Vários países de capitalismo avançado do pós-guerra, como França, Inglaterra, Japão, entre outros, também seguiram o modelo de uma economia mista em que os mercados fossem disciplinados pelo Governo. Obtiveram resultados positivos como baixas taxas de desemprego e altos índices de crescimento econômico, possibilitando a criação de um amplo mercado de consumo, no qual até mesmo famílias com rendimentos mais modestos eram capazes de comprar itens (geladeiras, ferro de passar, automóveis, telefones) que no passado estavam restritos a pequena parcela muito rica da sociedade. Em suma, nas nações de capitalismo avançado, os 30 anos que seguiram ao fim da segunda guerra mundial, até meados dos anos 70, apresentaram uma "espécie de casamento entre liberalismo econômico e democracia social". O período ficaria conhecido por historiadores, como Eric Hobsbawm (1995, p.264-268), pelo nome de "Anos Dourados" do capitalismo. O liberalismo laissez-faire com suas teses de não intervencionismo pareciam ser coisa do passado.

Nos Estados Unidos, no entanto, a época de ouro do capitalismo não era enxergada como dourada por todos. O medo de que as intervenções trazidas pelo New Deal levassem os EUA a uma decadência cultural e econômica que deixasse de cultivar a religião e o indivíduo, e ao invés disso pregasse o coletivismo e o socialismo — que em última instancia conduziria a nação ao totalitarismo - era um temor real para alguns indivíduos. Especialmente quando se pensava nos horrores da Segunda Guerra, seja nas atrocidades nazistas ou no grande espanto gerado pelo lançamento das bombas atômicas no Japão, que varreram do mapa Hiroshima e Nagasaki. Além, é claro, da União Soviética que com a queda Hitler e da Alemanha Nazista esta materializará, de agora em diante, o risco da destruição do Ocidente e da liberdade. (NASH, 2006, p.1)

Estas pessoas, chocadas com o estado atual do mundo e dos Estados Unidos em particular, se subdividiam em três grupos: Libertários, Tradicionalistas e Anticomunistas. Os primeiros, como

político que viria a ser o atual conservadorismo norte-americano.

4 O dicionário de economia definiu laissez faire como: "Palavras de ordem do liberalismo econômico, proclamando a mais absoluta liberdade de produção e comercialização de mercadorias. O lema foi cunhado pelos fisiocratas franceses no século XVIII, mas a política do laissez-faire foi praticada e defendida de modo radical pela Inglaterra, que estava na vanguarda da produção industrial e necessitava de mercados para seus produtos. Essa política opunha-se radicalmente às práticas corporativistas e mercantilistas, que impediam a produção em larga escala e resguardavam os domínios coloniais. Com o desenvolvimento da produção capitalista, o laissez-faire evoluiu para o liberalismo econômico, que condenava toda intervenção do Estado na economia." (SANDRONI, 1999, p.329) 
já foi dito, criticavam principalmente os novos papeis regulatórios do Estado, além de defenderem uma política externa isolacionista por parte dos EUA (RAIMONDO, 2008). Os segundos afirmavam que o New Deal simbolizava o auge no desenvolvimento de uma sociedade de massas que não se guiava pela religião e nem pelos "valores tradicionais cristãos" da sociedade ocidental. E os terceiros se encontravam em constante estado de guerra contra as ameaças de um perigosíssimo e poderoso oponente, o comunismo, que para eles buscava nada mais, nada menos, do que a dominação mundial (NASH, 2006, p.xv-xvi).

Contudo, por mais que tais grupos manifestassem sua resistência ao New Deal desde o começo da Depressão, estes ainda não apresentavam um movimento organizado e coeso de oposição. Apenas a partir de 1945 é que as convicções de libertários, tradicionalistas e anticomunistas passarão, gradativamente, de pensamentos desorganizados e isolados a um movimento político e intelectual coeso, capaz de difundir e unificar os ideais dos três segmentos, e gerar o fenômeno que ficaria conhecido no pós-guerra pelo nome de Nova Direita (NASH, 2006, p.xv).

Este processo de união e consolidação de forças entre intelectuais com matrizes pensamento dissemelhantes - como por exemplo, libertários que geralmente eram racionalistas e individualistas, e muitas das vezes não atribuíam a menor importância ao pensamento religioso e aos supostos valores de ordem difundidos pelos tradicionalistas. Estes últimos, que por sua vez enxergavam no acentuado individualismo e no livre mercado completamente desregulado do libertarianismo, uma ameaça à sua visão ideal de sociedade - não foi automático, nem aconteceu de forma linear. Pelo contrário, levou pelo menos uma década para que um novo conservadorismo que abarcasse ideais destes três grupos e articulasse críticas bem direcionadas e canalizadas ao Estado de Bem-estar social, no âmbito doméstico, e a União Soviética, no plano exterior, emergisse (SOUZA,2013, p.151-152). E como se verá mais adiante, este renascimento de uma nova direita também gerou cisões dentro do movimento. Para demonstrar um pouco melhor os caminhos e os descaminhos do conservadorismo, dois jornais merecem ser brevemente ressaltados: o Human Events e o (já mencionado) The Freeman.

O Human Events inicialmente tinha como meta ideológica os ideais de oposição da direita do entre guerras. Difundia em suas publicações o laissez-faire, a diminuição do poder do executivo, o privilégio do indivíduo como contraponto ao socialismo, a acentuação da autonomia dos estados norte-americanos frente à União e a suspensão de intervenções dos EUA em outros países, para assim restaurar a liberdade na América (SOUZA,2013, p.154). Entre seus autores estavam figuras proeminentes como o empresário Pierre Du Pont, o ex-presidente Hebert Hover, o ativista Charles Lindeberg, e políticos republicanos importantes como Robert Taft, o futuro presidente da República Rixard Nixon, além de intelectuais libertários como Friedrich Hayek, e tradicionalistas como Russel Kirk. Contudo, a revista gradualmente abandonou suas posturas a favor do não intervencionismo, por uma posição favorável a uma política externa intervencionista de forte cunho anticomunista (SKAGGS, 2014, p.167). E para a implantação desta política tudo era justificável, mesmo que fosse necessário o avanço da interferência estatal na sociedade.

Além disso, o formato que a revista possuía e as temáticas geralmente abordadas, também não eram tão atrativas. Focando principalmente em questões envolvendo a política externa dos EUA, cada edição do jornal cobriria apenas dois tópicos. O primeiro, quase sempre voltado para as relações internacionais, seria abordado em quatro artigos possuindo no máximo 1200 palavras, sendo cada um escrito por um autor diferente, fornecendo assim ao leitor pontos de vistas distintos sobre a mesma questão. Depois de quatro textos tratando da política exterior, os editores poderiam colocar um artigo que se debruçasse sobre assuntos internos, ou outra temática de sua própria 
escolha, sendo que na maioria das vezes o tema escolhido estava ligado ao anticomunismo (SKAGGS, 2014, p.164). Este formato fez do "Human Events mais um panfleto do que de fato um jornal" (SKAGGS, 2014, p.187)

Com a decadência do Human Events, o The Freeman passa a ocupar o seu lugar como uma forma de preencher "uma necessidade urgente na América para um periódico de opinião devotado à causa do liberalismo tradicional e da liberdade individual. O Freeman é feito para preencher essa necessidade." (HAMILTON, 1999 apud SOUZA, 2013 p.155). Para alcançar tal objetivo, nomes de peso como Hayek e Mises foram recrutados. Dessa forma, o The Freeman passa a representar os ideais do segmento libertário de não intervenção no estrangeiro, além da

[...] crença na autonomia moral do indivíduo, sem a qual não poderia haver liberdade alguma. Segundo [a qual], indivíduos livres agem por meio do livre mercado, "a instituição básica de uma sociedade liberal". A liberdade econômica e o livre comércio colocam a verdadeira sociedade liberal ou libertária à parte de todas as formas de coletivismo. (HAMILTON, 1999 apud SOUZA, 2013 p.156).

Contudo, a decadência financeira somada às brigas entre os editores no tocante ao macarthismo e às eleições republicanas, fariam a revista realinhar seus ideais em torno do anticomunismo intervencionista, impedindo que o The Freeman se tornasse um bastião do conservadorismo dentro dos EUA.

A mudança de postura que ambas as revistas vivenciaram em relação a política externa ao abandonarem o Isolacionismo em prol de um intervencionismo anticomunista - revela, na verdade, uma das principais questões do movimento até então, que é como lidar com a GuerraFria entre a União Soviética e os EUA. Isso gerou divisões no conservadorismo em que de um lado se encontravam os libertários, que defendiam o não engajamento dos EUA em assuntos estrangeiros. E do outro estavam tradicionalistas e anticomunistas, cuja a melhor postura a ser adotada pela nação seria partir para uma política externa mais ativa e combatente contra a URSS e outros países recém comunistas como a China.

Este duelo foi travado em uma série de artigos ao longo dos anos de 1954-1955. Libertários como Murray Rothbard (sob o pseudônimo “Aubrey Hebert”) (ROTHBARD, 2007, p.131) e Frank Chodorov, desmentem a crença difundida a respeito da URSS representar uma ameaça a própria existência dos EUA. Afirmando ser extremamente improvável que os soviéticos lancem mão de uma tentativa de invasão a América, pois de acordo com eles a Rússia não teria condições de levar a cabo tal ataque. Mas caso esta tivesse, de nada adiantaria pois os russos tem noção de que o poder de retaliação norte americano seria capaz de reagir a tal agressão com grande eficácia. Até porque a economia americana-por ser baseada no livre mercado- é, segundo os autores, mais produtiva do que a soviética. (CHODOROV, 1954b, p.172-173)

Além disso, para os libertários, os anticomunistas também estão errados ao analisarem a postura militar da URSS em relação a política estrangeira. De acordo com eles a União Soviética apenas se arma para defender-se militarmente, e ao contrário do que outros conservadores pensam ela não busca expandir seus territórios se utilizando da guerra como ferramenta de agressão direta, mas sim por meio da "Paciência, somado ao apoio prestado a partidos Comunistas e a filosofia no exterior, [este] parece ser o plano soviético". Dessa forma, a "ameaça militar russa é em sua maioria, um espantalho; os comunistas provavelmente são honestos em sua afirmação de que seu armamento é destinado à defesa.” (HEBERT [Murray Rothbard], 1954, p.23)

Ademais, um conflito direto com a URSS não traria mais liberdade para os americanos mas 
sim, o oposto, pois além do fato, de que uma disputa armada poderia derrotar apenas as nações comunistas em si, e não o comunismo enquanto ideologia, (Idem) é "durante guerra [que] o Estado adquire poder à custa da liberdade, e que por causa de sua luxúria insaciável por poder, o Estado é incapaz de desistir de qualquer porção obtida. O Estado nunca abdica." (CHODOROV, 1954a, p.81). Devido a isso, o "verdadeiro" inimigo a ser combatido na percepção libertária é "toda [forma] de estatismo e não apenas a variação comunista" (HEBERT [Murray Rothbard], 1954, p.23). É o estatismo que leva a perda de liberdade ao estabelecer a cobrança coercitiva de impostos para fornecer ao indivíduo uma proteção que, supostamente, este não deseja. Não lhe oferecendo, assim, a possibilidade de dispor de sua própria renda para contratar os serviços de proteção que desejar no livre mercado (Idem, p.25). Além disso, é em tempos de guerra que o Estado coloca em risco, com mais veemência, a liberdade individual, ao se valer dos tributos e da manipulação da opinião pública para custear a defesa nacional, ancorada na servidão involuntária do alistamento. (CHODOROV, 1954a, p.81) É com o intuito de combater o crescimento do governo e os prováveis excessos e violações da liberdade individual decorrentes deste agigantamento, que os libertários advogaram o isolacionismo. Pregando que:

O estado deve fazer o melhor para colocar limites e regras sobre a guerra, e para proibir o maior número de armas de destruição possível - começando com as piores. Além disso, enquanto a emergência permanecer, todos os esforços devem ser mantidos de forma voluntária, sem recrutamento, controles econômicos ou inflação.(...) Em resumo, (...) [o Estado deve] limitar seus objetivos, defender o Território nacional em vez de atacar, abster-se de um caminho para a vitória e rendição incondicional, e negociar a paz o mais cedo possível. (HEBERT [Murray Rothbard], 1954, p.26)

Já anticomunistas como William Schlamm e William Henry Chamberlin, ressaltavam os eminentes perigos de não se tomar medidas drásticas contra a União Soviética. Entendida como um como um inimigo mortal, composto por:

Um grupo de ditadores revolucionários fanáticos, comprometidos com a destruição das liberdades humanas básicas em todo o mundo, e detentores de um enorme império eurasiático que se estende de Stettin a Cantão, do Báltico ao Pacífico. É um império maior em área, população e recursos do que de Genghis Khan, ou de Napoleão, ou de Hitler. (CHAMBERLIN, 1954, p.12)

Ao contrário dos libertários que viam o processo de militarização da URSS como um sinal de autopreservação, os seus colegas conservadores anticomunistas entendiam que os investimentos soviéticos na área militar, tinham por intenção final não reforçar defesas, mas, o de invadir e dominar as fronteiras de outros países com a finalidade de, eventualmente, alcançar o mundo inteiro. Se valendo de "uma mistura de propaganda subversiva, agitação e força armada" (CHAMBERLIN, 1954 p.13) para realizar tal objetivo.

O segmento anticomunista argumentava que diante de um oponente desta magnetutude, as estrtégias isolacionistas dos libertários de não intervenção, retirada de trpoas ou o não engajamento em um conflito aberto, eram insuficientes e, portanto, deveriam ser repudiadas pelo novo conservadorismo. Para lidar com o perigo da União Soviética, eles apoiavam a formação de coalizões entre nações com líderes não comunistas e a utlização do exército norte americano no exterior para intervir em regiões que estariam, supostamente, sofrendo com ameaça do comunismo. As palavras do jornalista anticomunista William Chamberlin, simbolizam o pensamento da direita 
defensora de um EUA mais intervencionista no plano internacional. Segundo ele: "Já está na hora de perceber que ao lidar com um inimigo implacável empenhado em nossa destruição, não há salvaguarda em recuar, não há segurança na covardia, não há paz no apaziguamento" (1954, p.14)

Em suma, para resistir ao cenário de Guerra Fria, as intervenções estatais que são as principais preocupações dos libertários, ficam em segundo plano para os anticomunistas. Estes preferem um mundo livre da União Soviética e do comunismo, do que viverem em uma sociedade que possua um Estado sem papéis regulatórios e um mercado livre de restrições, porém, seja incapaz de lidar com a ameaça soviética. William Schlamm exemplifica, esta postura ao dizer que:

Eu estou, é claro, ciente do risco inerente de: deixar que as decisões sobre tempo e local de batalha mais adequados [sejam tomadas] por "especialistas" burocráticos e despensáveis, que podem ser movidos por convicções menos libertárias do que as minhas [próprias convicções].Mas, já que estou disposto a morrer do que vegetar sob um regime comunista, eu naturalmente também tenho que estar disposto a pagar o valor recuperável da perda de algumas de minhas liberdades para ter uma chance de evitar, durante séculos, a perda total da liberdade. (1954, p.171)

Por mais que o anticomunismo no que tange a política externa tenha criado divisões entre os diferentes segmentos da Nova Direita, nenhuma delas foi significativa a ponto de enfraquecer o movimento como um todo. Em geral, o argumento de que a Guerra fria só seria vencida se os EUA optassem pelo intervencionismo anticomunista ao invés do isolacionismo, foi bem aceito dentro do conservadorismo do pós-guerra. O próprio Rothbard diria depois que mesmo com tais discordâncias todos os debates ocorreram com tranquilidade (NASH, 2006, p.123). Isto se deve, em parte, ao fato de que muitos tradicionalistas, assim como seus pares anticomunistas e até mesmo alguns libertários, não viam nenhuma contradição em advogar por ideias pró-mercado e menos regulações estatais no âmbito doméstico, e a adoção de uma postura intervencionista no plano internacional para conter e, se possível, eliminar a "ameaça" soviética (NASH, 2006, p.124-5). O mesmo pode ser dito para os libertários que escreviam para o Human events e o The Freeman: embora nenhum dos dois periódicos tenham sido extintos, ambos perderam espaço e prestígio dentro das publicações conservadoras.

\section{National Review e a cisão do movimento}

O depauperamento do Human events e o The Freeman abriu espaço para que outro veículo de imprensa conservador emergisse. E este veio a surgir em 1955, com periódico National Review, fundado por William Buckley Jr. e William Schlamm. Com grande êxito, esta revista foi capaz de integrar nas suas publicações os ideais destes três setores, auxiliando na consolidação e na unificação de libertários, tradicionalistas, e anticomunistas, a fusão que caracterizaria conservadorismo do pós-guerra.

National Review era uma publicação eclética. Nota-se claramente a tentativa de aglomerar as diferentes tendências do conservadorismo. Defendendo em seu estatuto os princípios libertários de que

o governo tende a diminuir a liberdade e dificultar o progresso. O crescimento do governo (a característica social dominante deste século) deve ser combatido implacavelmente. Neste grande conflito social da época, estamos, sem reservas, no lado libertário(...)O sistema de preços competitivos é indispensável à liberdade e ao progresso material. (BUCKLEY,1955) 
Ecos tradicionalistas alertando sobre uma crise na sociedade, também aparecem entre os princípios da revista

A profunda crise da nossa era é, em essência, o conflito entre os Engenheiros Sociais, que procuram ajustar a humanidade para se conformar com as utopias científicas, e os discípulos da Verdade, que defendem a ordem moral orgânica. (...) Neste ponto, estamos, sem reservas, do lado conservador. (BUCKLEY,1955)

E por último, mas não menos importante, a defesa do anticomunismo intervencionistas em detrimento do isolacionismo na política externa (reflexo direto da vitória dos conservadores anticomunistas no debate ocorrido anteriormente sobre como lidar com a Guerra Fria) também se faz presente dentro dos posicionamentos da revista.

\begin{abstract}
A força mais estridente do utopismo satânico no século é o comunismo. Consideramos que a "coexistência" com o comunismo não é desejável nem possível, nem honrosa; nos encontramos irrevogavelmente em guerra com o comunismo e nos opomos a qualquer substituto para a vitória. (BUCKLEY,1955)
\end{abstract}

Por mais eclética que esta publicação se propunha a ser, ela não foi capaz de agradar o campo conservador em sua totalidade. Alguns intelectuais libertários (agrupados em torno de Murray Rothbard) afirmavam que a luta contra o comunismo estava sendo usada como desculpa pelo periódico, para legitimar qualquer tipo de intervenção estatal seja na sociedade norte-americana ou no estrangeiro. Colocando a liberdade individual em risco. Para eles, nas palavras do ativista libertário Ronald Hamowy, a revista estava defendendo cada vez mais veementemente

(1) uma política externa beligerante com possibilodades de resultar em guerra; (2) a supressão das liberdades civis no ambito doméstico; (3) uma devoção ao imperialismo e a uma forma refinada de supremacia branca; (4) tendência à união da Igreja com o Estado; (5) a convicção de que a comunidade é superior ao indivíduo (...) (6) um apoio bastante indiferente à economia [de] livre[mercado] (...). Eles não desejam muito limitar o Estado mas sim controlá-lo. (1961, p.104)

A resposta de William Buckley foi reafirmar o compromisso da National review com o libertarianismo. Dizendo que a "única defesa contra as deficiências e abusos da ação coletiva do Estado é a resistência coordenada dos indivíduos" (BUCKLEY,1961, p.106), citando os membros libertários (como Henry Hazlitt e Frank Meyer) que compunham o conselho editorial da revista, e reportagens publicadas por esta que reafirmavam a importância do livre mercado e questionavam as políticas regulatórias aplicadas pelo Banco Central norte-americano (1961, p.104-5). Quanto a acusação de que a política externa adotada pela National Review seria beligerante a ponto de resultar em guerra, Buckley (1961, p.105). responde não saber que "para ser um verdadeiro libertário você deve amar a liberdade, mas não tanto - [pois] você deve preferir ser [um comunista] vermelho do que um cadáver", ou você não pode estar na tradição libertária". Além de ressaltar que é apenas "por causa da disposição dos conservadores em se sacrificar a fim de resistir ao inimigo, que eles [os libertários] são capazes de desfrutar de seu monasticismo e de montarem seus atarefados pequenos seminários sobre se devem ou não desmunicipalizar os coletores de lixo.” (1961, p.107)

Daí por diante, as relações entre estes libertários e a National Review apenas se deteriorariam

5 Better red than dead na versão original 
até a expulsão de Rothbard e seus seguidores daquilo que estava se tornando a principal liderança e tendência do movimento conservador. Em 1962, o conservador libertário e anticomunista, Frank Meyer, oficializaria a exclusão do libertarianismo isolacionista.

Recentemente, no entanto, surgiu pela primeira vez uma determinada posição, desenvolvida a partir do setor "puro libertário" da opinião de direita, que repudia veementemente a luta contra o principal e mais imediato inimigo contemporâneo da liberdade, o comunismo soviético - e o faz por motivos, supostamente, de amor à liberdade(...)Pode parecer que não adianta discutir uma visão da realidade tão patentemente distorcida que possa considerar o apaziguamento do comunismo, e nós que nos desarmarmemos antes do impulso armado comunista e de [sua] aliança com aqueles que facilitam o caminho para a vitória comunista, como essenciais para a defesa da liberdade do indivíduo(...) É uma tendência que, [se] não controlada, pode ser (...) prejudicial ao desenvolvimento de uma posição conservadora americana madura (MEYER, 1962)

Tendo em vista este cenário em que uma tentativa de se reaproximar da direita parecia impossível e diante da necessidade de "avançar com o minúsculo e disperso movimento libertário anarco-capitalista ${ }^{6}$; para converter esses libertários, a pelo menos, uma posição solidamente isolacionista." Rothbard (2007, p.187) e seus seguidores se viram cada vez mais atraídos a buscarem uma aliança com os membros da Nova Esquerda, pois os dois movimentos enunciavam posturas isolacionistas e antiguerra, além de possuírem posicionamentos similares a favor dos direitos civis.

Embora a Nova Esquerda parecesse ser o grupo ideal para se efetivar uma nova aliança e diminuir a marginalização política que estes anarcocapitalistas enfrentavam, ainda pairava no ar uma questão. Mas como fazer isso? Em suas memorias Rothbard nos diz que

O surgimento da Nova Esquerda convenceu Leonard [Liggio] e eu que chegara a hora de agir, de romper com o nosso ideológico e isolamento político. Assim, fundamos, na primavera de 1965, o periódico que possuiria três edições por ano Left and Right [: a Journal of the Libertarian Thought]. L \& R [Left and Right] foi fundada com o duplo propósito de: influenciar libertários ao redor do país a romper com a direita e aliarem-se com a emergente Nova Esquerda e tentar empurrar esta esquerda ainda mais em uma direção libertária; e segundo, nos "encontrarmos" na própria Nova Esquerda, como um grupo no qual poderíamos nos aliar e possivelmente influenciar (2007, p.193).

\section{A Nova Esquerda}

Nos EUA, a esquerda tradicional - geralmente pautada no marxismo soviético — vivenciava um agudo declínio nos anos posteriores a Segunda Guerra. Por exemplo, o partido comunista viu seu número de adeptos cair de 75000 em 1945 para 3000 em 1958. No âmbito doméstico a situação confortável trazida pelo Estado bem-estar social, somada a perseguição causada pelo anticomunismo estridente, o Macartismo, e as denúncias de Nikita Kruschev sobre os crimes do Stalinismo ajudaram a criar este quadro de decadência para o partido e para outros grupos marxistas

\footnotetext{
60 pensamento libertário pode ser dividido em duas correntes principais: Os minarquistas, que acreditam que o mercado deve ocupar todas as áreas, excetuando-se apenas as instituições jurídicas, e as forças que lidam com a segurança pública e nacional (como a polícia e as forças armadas). Um exemplo desta perspectiva é o livro do filósofo Robert Nozick Anarquia, Estado e Utopia (1991). Já os anarcocapitalistas defendem que até mesmo os serviços prestados pelas forças de segurança e pelos tribunais, seriam mais eficientes caso fossem administrados pelo livre mercado. Um exemplo desta perspectiva é o livro As Engrenagens da Liberdade de David Friedman (1973)
} 
comum todo (ROBERT, 2016, p.112-113).

No entanto, este contexto deixou espaço para que uma nova força política à esquerda pudesse florescer e no final dos anos 50, início dos 60 novos movimentos emergiram ao redor do mundo buscando rever os erros do comunismo soviético e em alguns lugares, como nos EUA, até se distanciar deste. Este fenômeno de mudança e renovação da esquerda a nível mundial ficará conhecido pelo nome de Nova Esquerda.

Como nos diz o historiador Rodrigo Farias de Souza (2009, p.16-17), a Nova Esquerda caracterizava-se por ir além do mero combate à desigualdade de renda, privações materiais, e organização política do operariado, que pautavam a (agora chamada de) Velha Esquerda. Ela focava na luta contra as discriminações raciais e de gênero, buscando criar uma cultura antiautoritária capaz de fazer com que todos os cidadãos (independente de raça e gênero) participassem da democracia de forma igualitária. Tentava evitar sua burocratização, que para os membros da Nova Esquerda, seria a principal responsável por afastar a política do cotidiano das pessoas, auxiliando na criação de cidadãos alienados da própria sociedade em que vivem.

Para isso um ideal central para Nova Esquerda estadunidense, principalmente para a $\mathrm{SDS}^{7}$ - o principal movimento da esquerda estudantil norte americana - era o conceito de democracia participativa. Os novos esquerdistas tinham como princípio que o liberalismo americano, embora tenha acertado ao diminuir as desigualdades econômicas, foi aos poucos se corrompendo por ir se burocratizando gradativamente, devido as demandas da Guerra fria e da Segunda Guerra Mundial. Isso deu margem para que uma elite política e econômica extremamente poderosa emergisse dentro do Estado e distanciasse cada vez mais a população da arena pública, do debate sobre os grandes temas nacionais e do processo de tomada de decisões. Com isso, para que o Estado de Bem-Estar americano pudesse ser aperfeiçoado, seria necessário politizar e informar a sociedade como um todo e, assim, conceber uma arena política em que todos tivessem uma voz engajada no debate sobre as questões relativas à comunidade. E, desse modo, construir uma democracia em que de fato todos participassem do processo decisório, e não apenas a pequena minoria burocratizada (SOUZA,2009, p.65-66). Como viria a dizer o documento fundador da SDS, a Declaração de Port Huron:

Como um sistema social, nós buscamos o estabelecimento de uma democracia de participação individual, governada por dois objetivos centrais: que o indivíduo tome parte nas decisões sociais determinantes da qualidade e do direcionamento de sua vida; que a sociedade seja organizada para encorajar a independência dos homens e prover os meios para a sua participação comum. (MILLER,1987 apud SOUZA, 2009, p.103)

Assim como na política, em termos econômicos, a Nova Esquerda se opunha a uma economia nacional burocratizada em que as decisões fossem tomadas de "cima para baixo". Na visão deles, para que o processo econômico se tornasse democrático de fato, todas as pessoas deveriam ter a sua parcela de responsabilidade na tomada de decisões. Em virtude disso, os membros da Nova Esquerda advogavam pela desburocratização do Economia (o que não quer dizer eliminar a capacidade deste para minorar as desigualdades sociais e de renda), a descentralização da tomada de decisões e fábricas geridas coletivamente pelos trabalhadores (SOUZA, 2009, p.18)

Ao contrário da Velha Esquerda que via o proletariado como o único agente de mudança, a Nova Esquerda entendia que outros grupos também podiam se juntar a este na missão de

7 Students for a Democratic Society 
transformar a sociedade. Principalmente os marginalizados, como as mulheres e os negros, mas também outros como estudantes e até mesmo setores da classe média. Tendo em vista este ideal de que a transformação da sociedade seria o produto dos esforços coletivos de vários agentes, os novos esquerdistas evitavam adotar posturas sectárias dentro do movimento, possibilitando que os mais diversos grupos políticos participassem de suas assembleias e eventos, indo desde grupos como o movimento negro, feministas, socialistas a até mesmo, como se mostrará mais adiante, libertários.

Para conseguir mobilizar estes grupos e colocar em prática a mudança que desejavam, os novos esquerdistas se valeram de outras técnicas que iam além das tradicionais greves e passeatas do movimento operário. Incorporaram táticas do movimento negro, como a ocupação de áreas públicas, apropriação de prédios, além de realizarem sit-ins ${ }^{8}$ e teach-ins ${ }^{9}$ para mobilizar as pessoas ao redor e chamar atenção para a causa realizando assim uma "oposição firme, mas dentro dos limites institucionais" (num primeiro momento pelo menos, pois no decorrer da década de 60 as manifestações da Nova Esquerda ficariam cada vez mais violentas). (SOUZA, 2009, p.20)

Estas diferentes visões a respeito de como mudar a sociedade, quais seriam os agentes responsáveis pela mudança, e que tipo de sociedade se quer criar, fizeram com que muitas vezes os novos esquerdistas entrassem em conflito com a Velha Esquerda e com os liberais. Os primeiros acusavam os participantes da Nova Esquerda de serem muito apegados ao status quo para de fato quererem mudá-lo. Os últimos foram se distanciando gradativamente da perspectiva novo esquerdista, na medida em que o Partido Democrata na figura do Presidente Lyndon Johnson, se enrolava cada vez mais com a Guerra do Vietnã, já que estes repudiavam fortemente o alistamento militar, bem como o envolvimento norte-americano no conflito, pregavam por uma política pacífica de coexistência com a União Soviética, além de defenderem o desarmamento nuclear.

\section{Left and Right: A journal of the libertarian Thought}

Tendo-se exposto brevemente, em linhas gerais, os princípios norteadores da Nova Esquerda, torna-se mais evidente o porquê dos libertários terem se esforçado em cooptá-los para dentro de seu movimento. As críticas destes últimos no tocante a participação dos EUA em guerras, a crescente burocratização do Estado americano e a defesa da descentralização e da autonomia individual como resposta para combater tais problemas, poderiam muito bem ter sido escritas por algum membro do movimento libertário. E são estes pontos de encontro que serão enfatizados pelos libertários na revista Left and Right: A Journal of the libertarian thought ${ }^{10}$. Como dizia o primeiro editorial da revista:

\footnotetext{
Nosso título, Left and Right, reflete nossas preocupações de várias maneiras.Ele revela nossa preocupação editorial com o ideológico; e destaca nossa convicção de que as categorias atuais de "esquerda" e "direita" se tornaram enganosas e obsoletas, e que a doutrina da liberdade contém elementos provenientes tanto da esquerda quanto da direita contemporanea(LEFT AND RIGHT,1965,p.7).
}

\footnotetext{
8 Os sit-ins consistiam na tática pacifista de se sentar num estabelecimento em que aplicava as leis de segregação e só se levantar apenas quando o responsável pelo espaço estiver disposto a abrir mão da segregação

9 Os teach-ins, consistiam na ocupação de determinado espaço por várias pessoas, com o intuito de debater e montar eventos sobre determinado tema político.

10 Para a escrita deste artigo utilizou-se a versão digital da revista referenciada nas citações bibliográficas no final do texto.
} 
Para provar o ponto de que o libertarianismo contemporâneo não seria um elemento constituinte do pensamento de direita, como advogava a National Review, e sim uma doutrina que na verdade teria muito em comum com a esquerda, o primeiro artigo da revista seria um ensaio (elevado posteriormente a categoria de clássico passando a ser leitura obrigatória para qualquer libertário) de revisionismo histórico escrito por Murray Rothbard intitulado Esquerda e Direita: perspectivas para Liberdade $(2010)^{11}$.

Rothbard inicia seu artigo declarando que muitos libertários veem, erroneamente, o libertarianismo como um elemento da direita e, devido a isso, entendem que uma aliança política com os conservadores não é apenas necessária, mas também natural. Para justificar seu posicionamento de que este não é o caminho a ser trilhado pelos libertários, Rothbard recorre a história, afirmando que o conservadorismo não passa de "um remanescente moribundo do Ancien Regime da era préindustrial, [e] não tem mesmo futuro" (ROTHBARD, 2010, p.14 grifo do autor). Dessa forma os conservadores representariam a "Velha Ordem" caracterizada pela "tirania, a exploração, a estagnação, as castas estanques, a desesperança e a fome para a maior parte do povo.” (Idem p.15)

Contudo essa "Velha Ordem" foi derrotada por causa de dois eventos fundamentais. O primeiro nos conta Rothbard, foi o surgimento e crescimento da indústria e do comercio, e o segundo foram as revoluções liberais burguesas do século XVIII, que abriram "caminho à Revolução Industrial e a vitórias, pelo menos parciais, da liberdade individual, do laissez-faire, da separação entre a Igreja e o estado e da paz internacional." (Idem p.16). Ancoradas no liberalismo clássico, elas retiraram a "humanidade de sua imemorial fossa de estagnação e desesperança." Em suma todo "progresso" era e sempre foi fruto da esquerda enquanto os retrocessos proviam da direita. (PAYNE, 2005, p.13-14)

No decorrer deste processo, Rothbard nos diz, que estas duas ideologias se polarizaram, sendo liberalismo clássico o representante da extrema esquerda revolucionária e conservantismo do Antigo Regime na extrema direita reacionária. A partir daqui o autor busca responder o que teria acontecido com o espectro ideológico para que o liberalismo laisseq-faire, que durante o século XIX havia sido classificado por seus defensores como uma ideologia radical e de esquerda, ao passo que no século XX este passou a ser considerado como uma ideologia conservadora e de direita.

A resposta para ele reside no fato de que o liberalismo clássico passou a se contentar cada vez mais com o status quo, já que a revolução liberal havia sido parcialmente bem-sucedida no ocidente. Isto deixou espaço para que o socialismo tomasse o lugar do liberalismo para continuar a luta contra o que havia restado da "Velha Ordem". Contudo embora o socialismo estivesse à esquerda do conservantismo, este "era essencialmente um movimento confuso, de cunho intermediário. (...) e ainda o é, por tentar alcançar fins liberais pelo uso de meios conservadores" (ROTHBARD,2010, p.19-21). Segundo Rothbard, de maneira semelhante ao liberalismo, o socialismo

aceitou o sistema industrial e as metas liberais de liberdade, razão, mobilidade, progresso, padrões de vida mais elevados para o povo, e um basta à tecnocracia e à guerra; mas tentou chegar a esses fins utilizando meios conservadores, incompatíveis com eles: estatismo, planejamento centralizado, comunitarismo etc.(Idem, p.21)

Esta contradição entre os meios e os fins políticos que acomete o socialismo,

${ }^{11}$ A publicação original deste texto data de 1965. Utilizou-se aqui a versão em português publicada em 2010, referenciada nas citações bibliográficas no final do texto 
eventualmente, fez com que este fosse incorporado ao conservadorismo, criando o fascismo. $\mathrm{Na}$ Europa, esta mistura criou num primeiro momento o regime antilibertário de Bismarck, e no século XX levou aos governos coletivistas de Mussolini e Hitler. Buscando implantar o militarismo, o nacionalismo o coletivismo de direita, e a estatização da sociedade (ROTHBARD,2010, p.31).

Nos EUA, esta combinação teria levado ao "fascismo social" com suas origens na Era Progressista e sua expressão mais bem-acabada no New Deal (KELLEY, 1997, p.95). Se valendo de interpretações de historiadores da Nova Esquerda como Gabriel Kolko ${ }^{12}$, Rothbard diz que durante a Era Progressista as grandes empresas, (e não os reformadores sociais do período) passaram a requisitar a atuação do Estado para engendrar o que ele chama de capitalismo monopolista estatista criando cartéis, trustes, inflação, planejamento centralizado, e incentivo a sindicatos que impediam o pleno funcionamento de uma economia de livre mercado. O New Deal teria sido apenas o ápice deste fenômeno, trazendo de novidade apenas o militarismo por decorrência da Segunda Guerra Mundial e o “adestramento” educacional em larga escala. Nesta versão, Roosevelt não seria o grande responsável por subverter o sistema americano - conforme dizia a narrativa conservadora - ele estaria apenas expandindo de forma quantitativa "a teia de privilégios concedidos pelo estado, já proposta e aplicada anteriormente: na administração de Hoover, no coletivismo de guerra da Primeira Guerra Mundial e no Período Progressista.” (ROTHBARD, 2010, p.28-29). Em suma, o progressismo do começo dos anos dez e o New Deal, seriam apenas uma reatualização para América do século XX de um antigo inimigo dos libertários, os restos do conservadorismo estatista da "Velha Ordem".

Entretanto, se estes movimentos nada mais eram do que uma tentativa de assalto ao poder, travestida de reforma política e social, levada a cabo pelo conservantismo de períodos pré-revolução, então por que os libertários não se ergueram na luta contra ele?

$\mathrm{O}$ autor explica que as tentativas perpetradas pelos grandes grupos empresariais de recorrer ao governo federal para impedir o funcionamento do mercado livre, levou "Tanto a direita quanto a esquerda (...) [a serem] persistentemente induzidas em erro pela noção de que intervenção do governo significa ipso facto esquerdismo e oposição aos interesses da grande empresa. Daí a mitologia, endêmica entre a direita, do caráter vermelho [comunista] do New (ou Fair) Deal." (Idem, p.29). Com esta confusão, a regulação estatal passou a ser considerada uma bandeira da esquerda, pegando os libertários de surpresa e deixando-os incapazes de discernirem quem seriam seus verdadeiros aliados na luta por uma sociedade sem Estado (ROTHBARD, 2010, p.36). E para combater as tendências estatistas do período, levadas a cabo por presidentes como Coolidge e Hoover (nesta narrativa revisionista, ambos os ex-presidentes não passam de meros defensores de um conservadorismo antilibertário), os libertários tiveram que fazer alianças de compromisso com os socialistas. No entanto, a chegada de FDR ao poder seduziu vários dos socialistas que estavam nesta frente ampla de oposição ao estatismo, restando aos libertários como única opção a união com os "conservadores mais antigos, que, por sua vez, foram obrigados a adotar uma fraseologia libertária (mas destituída de conteúdo libertário real) na oposição ao governo de Roosevelt que, a seu ver, tornarase demasiado coletivista, tanto na essência quanto na retórica" Forçando os libertários "a ostentar de bom grado o rótulo, antes menosprezado, de "conservador"” (Idem, p.35-36).

12 O livro que Rothbard usa para embasar sua reinterpretação da Era progressista é a obra do historiador Gabriel Kolko The Triumph of Conservatism (1977), originalmente publicado em 1963. Kolko afirmava que as reformas trazidas durante o período foi produto da ação de lideranças empresariais e não dos reformadores sociais desta época. Contudo, apesar dos libertários concordarem com sua análise do progressismo, Kolko era um socialista e se opunha aos ideais pró-livre mercado do libertarianismo 
Tendo exposto as razões históricas causadoras da confusão ideológica que aflige os libertários, Rothbard diz que o próximo passo para o sucesso do libertarianismo está em

retificar drasticamente sua concepção equivocada do espectro ideológico; (...) descobrir quem são seus amigos e aliados naturais e, talvez acima de tudo, quem são seus inimigos. Munido desse conhecimento, que prossiga nesse espírito de otimismo radical quanto aos resultados finais (ROTHBARD, 2010, p.42)

Embora ele não cite nomes, fica evidente que os "aliados naturais" dos libertários estão à esquerda e não a direita do espectro político. Mais do que isso, não é qualquer esquerda que deve ser contatada, já que o comunismo não é confiável pois ao longo da história ele próprio, supostamente, teria abdicado de seus ideais radicais e se unido ao conservadorismo para formar o Establishment, então alianças com a "Velha Esquerda" estavam fora de cogitação. A Nova Esquerda, por outro lado, parecia ser o aliado perfeito. Com isso em mente, e tendo "reorganizado" o espectro político para os libertários, faltava agora fisgar estes possíveis novos aliados de ideologia "vaga o suficiente para abranger até mesmo "libertários de direita"'. Uma forma de fazer isso foi traçar as diferenças entre a Velha Esquerda e Nova Esquerda e ressaltar o "instintivo sentimento libertário" (ROTHBARD, 2007, p.192) de organizações novo esquerdistas como a SDS. Isto foi feito na segunda edição da revista no ano de 1965, no artigo chamado "Liberty and the New Left" (ROTHBARD, 1965)

Para Rothbard, a "Velha Esquerda" deveria ser rejeitada por sua tendência em se acomodar junto ao Estado, os grandes empresários e outros grupos de interesse na formação dos privilégios característicos do que ele chama de capitalismo monopolista e Estado de Bem-Estar Social Bélico ${ }^{13}$, que, amarraria os EUA a uma democracia representativa, caracterizada pelo princípio de "desde que todos possam votar e os representantes da maioria governarem (...) não há nada para ninguém se preocupar"

Em crítica muito semelhante à da Nova Esquerda, Rothbard dirá que os velhos esquerdistas defendiam um sistema em que as pessoas estavam confinadas a um sistema passivo e manipulador de votar periodicamente em seus representantes, com o objetivo final de sempre conceder a estes últimos "carta branca" para que pudessem permanecer no poder e assim perpetuar tal sistema. Dessa forma, ele conclui que ênfase da "Velha Esquerda" está no estatismo representado pelo "planejamento Centralizado no âmbito doméstico, nas intervenções em nome da 'segurança coletiva', dentro dos assuntos de todo mundo e em guerras ao redor do planeta”. E já que a direita também sucumbiu ao militarismo e a estatização cabe agora ao novo esquerdismo carregar "a tocha da liberdade contra o Establishment" (ROTHBARD, 1965, p.125-126)

E como a Nova Esquerda deveria abordar a luta contra o sistema? Para os libertários, a democracia participativa e o ativismo fora da esfera estatal seriam a solução, já que ambas as táticas indicariam a índole libertária dos novos esquerdistas, demonstrando seu suposto desprezo "pelo estatismo e pelo reformismo social", (ROTHBARD, 1965, p.132) em contraponto com o velho esquerdismo que tentaria, por meio da ação estatal, impor sobre todos reformas desejadas apenas pelos membros do governo e não pela sociedade como um todo.

Dentro desta perspectiva libertária o conceito novo esquerdista de democracia participativa seria revolucionário, pois, além da descentralização política inerente a este, Rothbard argumenta que cada pessoa "participaria apenas dos projetos que considerar importante ou que valham a

13 Welfare-Warfare State no original 
pena” (ROTHBARD, 1965, p.129), ou seja, os indivíduos teriam liberdade de escolha um tipo de experiencia que para ele seria encontrada apenas em uma sociedade de livre comércio. Até porque, em sua visão, a única forma de se aplicar efetivamente o ideal de democracia participativa numa sociedade de cunho industrial seria por meio do livre mercado. (ROTHBARD, 1965, p. p.153)

Aqui Rothbard se vale do ideal de democracia participativa para enxergar a todo custo na Nova Esquerda uma concepção de sociedade ancorada no laissez-faire, algo que ela não possui. Como nos diz John Kelley (1997, 97), "Embora a Declaração de Port Huron, certamente incluiu pedaços de retórica "libertária", suas afirmações econômicas colidem fundamentalmente com os princípios economicos do laissez-faire". Segundo o próprio estatuto:

As corporações devem ser publicamente responsabilizadas. (...) A alocação de recursos deve ser baseada em necessidades sociais ... Todas estas tendências sugerem que as soluções não só para as nossas necessidades sociais presentes, mas também para a nossa futura expansão repousa sobre a nossa vontade de ampliar o "setor público" enormemente (KELLEY, 1997, p.103)

Mesmo com estas divergências no campo da economia, para Rothbard, havia ainda outros elementos dentro do novo esquerdismo que apontariam diretamente para uma possível direção libertária. Ao contrário da Velha Esquerda que alcançava seus objetivos se valendo do Estado por meio de práticas desprezíveis como a formação de lobbys no congresso. O novo esquerdismo, em contrapartida, utilizaria mecanismos de ação direta para atingir seus fins, enfatizando a construção de instituições paralelas como as "Universidades Livres"14 e o ERAP" e organizando grandes protestos de desobediência civil. Estas atitudes, seriam indícios de que a Nova Esquerda estaria se aproximando do libertarianismo, pois o ativismo fora da esfera estatal era o que a diferenciava do velho esquerdismo.

É por isso que Rothbard reivindicará o anarquista Henry Thoreau (1817-1862) como um dos grandes influenciadores da tática de desobediência civil dos novos esquerdistas, além de ressaltar que o velho direitista Frank Chodorov foi quem mais advogou os ideais Thoreau no pósguerra. O que em sua visão, provaria ser "um exemplo instrutivo (...) do modo pelo qual os ideais libertários passaram inconscientemente da Velha Direita para a Nova Esquerda" (ROTHBARD, 1965, p.131).

Em suma, o fato dos novos esquerdistas buscarem enfatizar o ativismo político direto para além da luta por dentro do sistema e possuírem uma visão de sociedade na qual a participação política e a educação dos indivíduos precisa ser desburocratizada e descentralizada para que a democracia pudesse de fato florescer, induziu libertários, como Rothbard, a acreditarem que

Em suas lutas concretas contra a opressão centralizada, os jovens militantes da Nova Esquerda estão se movendo, em grande medida de maneira não intencional, mas com uma consciência cada vez maior, (...) em direção a uma visão de futuro que seja a mais ampla extensão possível dos ideais de liberdade, independência e democracia participativa: um livre mercado em uma sociedade livre.(ROTHBARD, 1965, p.155 grifo nosso)

\footnotetext{
14 Eram espaços formados por estudantes e militantes políticos da Nova Esquerda, em que se realizava o debate sobre temas e se oferecia cursos sobre assuntos fora do currículo universitário oficial. Uma das principais iniciativas neste sentido foi a Universidade Livre de Nova York.

15 Foi uma das primeiras iniciativas da Nova Esquerda fora dos limites físicos da universidade, inspirado em associações do movimento negro o Economic Reserch Action Project (ERAP) tinha como objetivo organizar e mobilizar pobres desempregados brancos para que futuramente se pudesse pensar em uma aliança entre brancos e negros na defesa de reformas sociais
} 
Devido a isso ele continuou empenhado em aprofundar estes laços entre esquerda e direita. Apoiando a eleição da ala que considerava como a mais radical da Nova Esquerda composta, segundo ele, por jovens ativistas que desprezam "a ideologia marxista ou socialdemocrata [d]e [criar uma] coalizão confortável, [e] que, embora sejam muitas vezes incoerentes, são anti-estatistas e instintivamente libertários ao âmago de seu ser." Em contraposição a esta "Nova Guarda”, estava a agora nomeada de "Velha Guarda" do novo esquerdismo, que para Rothbard, mesmo esta última sendo um grande avanço em relação a "Velha Esquerda" ela "ainda permanece estatista e socialdemocrata em seu núcleo" tendo como objetivo final "reintegrar a SDS no antigo sistema de coalizão partidária e nos do grupos de pressão política”(ROTHBARD, 1967, p.368), o que para o autor em última instancia significa domesticar a SDS retirando dela sua vontade de alterar o sistema em troca por um lugar no Establishment norte americano.

Vendo na nova geração de ativistas uma oportunidade de colocar libertários em contato com o que entendia ser o "melhor" da Nova Esquerda - devido aos posicionamentos das novas levas em favor de medidas mais enérgicas contra a guerra do Vietnã, como a organização mais regular de demonstrações anti-guerras, e a sua total aversão ao alistamento (ROTHBARD, 1967, p.371) - levaram Rothbard a atacar a Declaração de Port Huron, afirmando que esta seria a prova de que os membros mais antigos da SDS teriam posições estatistas parecidas com as da Velha Esquerda, já que o Estatuto defendia "a noção equivocada de que o governo é - um instrumento do povo para fiscalizar as grandes empresas, mas que os empresários conseguiram manter esse controle fraco - o argumento central da posição da velho esquerdista" (ROTHBARD, 1967, p. 369)

É interessante notar como até então, desde a primeira publicação da revista, a Declaração de Port Huron nunca havia sido criticada, bem como os princípios econômicos da Nova Esquerda. Parece que com o aprofundamento desta aliança os libertários se sentiram mais à vontade não apenas elogiar os novos esquerdistas, mas também para criticá-los nos pontos em que possuíam alguma divergência de ideias. Além disso atacar Velha Guarda da SDS seria útil para solidificar alianças com a Nova Guarda, já que, é na segunda metade da década de 60 que a SDS verá seu número de membros quase quintuplicar em relação aos anos iniciais (SOUZA, 2009, p.214-.215). Ou seja, as investidas contra determinados setores do novo esquerdismo para além de representar simplesmente uma mera discordância de pensamento, teriam também caráter oportunista.

Para reforçar ainda mais essa a aliança e tornar o libertarianismo mais atraente para a Nova Esquerda, Rothbard publica em $1968^{16}$, ano em que esta havia atingido seu auge, um artigo na revista Ramparts uma das principais publicações universitárias do novo esquerdismo. O texto se chama Confessions of a Right-Wing Liberal, e é uma análise retrospectiva na trajetória de vida do autor contando os acontecimentos que o levaram a reavaliar sua posição no espectro político.

vinte anos atrás eu era um republicano de extrema-direita,(...) que acreditava [que] o "senador [Robert] Taft tinha se vendido aos socialistas". Hoje, é mais provável que eu seja chamado de extremo esquerdista, já que sou a favor da retirada imediata do Vietnã, denuncio o imperialismo dos EUA, advogo em favor do Poder Negro e acabei de entrar para o novo Partido da Paz e Liberdade. E, no entanto, minhas opiniões políticas básicas não mudaram nem um pouco nessas duas décadas! (ROTHBARD,2016, p.151)

Segundo ele, a averssão ao militarismo, ao alistamento e a outras formas de controle

16 O artigo original é de 1968, contudo a versão utilizada aqui é uma edição republicada em 2016 
estatista, assim como, a defesa da liberdade economica e da autonomia individual estariam representadas na direita republicana, logo, ele aceitava o especto político padrão de que " 'Esquerda' significava socialismo ou poder total para o Estado; e quanto mais para a 'direita' alguém fosse menos governo [esta pessoa] desejaria. Por isso nos chamávamos de 'extrema-direita"' (ROTHBARD,2016, p.152)

Contudo, para Rothbard, dois fatores fundamentais desviaram a direita de sua direção libertária. O primeiro evento teria sido o macarthismo, que teria incutido na direita toda retórica referente ao anticomunismo, que até aquele momento seria uma característica da esquerda liberal, não incluindo políticos republicanos - já que para o autor as primeiras medidas de repressão aos comunistas teriam acontecido nas administrações liberais de Roosevelt e Truman. Versão esta que ia na contramão de conservaodres da direita anticomunista que atribuíam com frequência aos governos democratas o rótulo de comunistas, ou de pelo menos adeptos parciais da ideologia. (ROTHBARD,2016, p.154)

É importante perceber como as memórias do anticomunismo do imediato pós-guerra ainda estavam em disputa pela direita naquele momento, tendo cada autor utilizado-as conforme seu próprio interesse. Os integrantes da Nova Direita acusavam os liberais democratas de serem adpetos, ainda que parcialmente, do comunismo e usaram isso a seu favor para resistir aos governos do Partido Democrata e tentar monopolizar os discursos referntes a política externa (BJERREPOULSEN, 2013, p.19). Enquanto os libertários que haviam rompido com a National Review, afrimavam que a postura anticomunista dos anos 40 estava ligada aos democratas, já que fazia parte da estratégia libertária separar os grupos novo esquerdistas do mainstrem liberal daquele momento.

O outro evento que teria transformado a direita seria a adoção do termo conservador em decorrencia da obra The Conservative Mind ${ }^{17}$ de Russel Kirk. Segundo Rorthard, Kirk, ao vincular o termo conservador com a direita, e definir o conservadorismo como a defesa da tradição, preservação da hierarquia e da ordem e apologia à religião cristã contra as "blasfemias" modernas materializadas no progreso, razão, ciencia, e ateísmo, teria feito com que toda uma nova geração homens da direita não encarassem as questões referentes ao "Estado vs liberdade individual, da intervenção governamental vs livre mercado" (ROTHBARD, 2016, p.155-156), que seriam o "verdadeiro problema" em sua visão.

Estes dois acontecimentos além de desfigurarem a direita, também gerou como consequencia uma aproximação desta com o Establishment liberal, criando uma outra alinaça esquerda/direita, só que de caráter centrista e conservador. De acordo com Rothbard, bastava apenas olhar na mídia para perceber a atenção que uma quantidade considerável de intelectuais do novo conservadorismo estão recebendo de jornais e programas de TV liberais.

A Guerra no Vietnã seria outro exemplo. Para ele, qualquer um podia notar que defensores do conflito são os editores da National Revein e políticos estatistas democratas, além é claro de representantes do Partido Republicano que estavam se tornando cada vez mais alinhados com os interesses da Nova Direita. E na política interna este aderimento da direita ao Estblhishment também se manifestaria nos

\footnotetext{
17 Esta obra foi uma das mais importantes publicações da direita do pós-guerra. Publicada originalmente em 1953, nela Kirk tenta compreender o que significa ser conservador no século XX, elaborando uma genealogia de autores conservadores para o movimento. Além de construir um conjunto de princípios que caracterizariam o conservadorismo e enfatizar quais são os preceitos que o movimento deveria rejeitar (KIRK, 2001, p.36-38)
} 
interesses conservadores (...) [para] suprimir os negros (...) pedir mais poder para a polícia não com o intuito de "proteger o criminoso" (ou seja, não defender seus direitos libertários), reforçar a realização das orações nas escolas públicas, colocar os comunistas e outros subversivos e "incitadores" na cadeia, e continuar a cruzada em direção a guerra no exterior. Existem poucos itens neste programa com o qual os liberais discordariam agora; quaisquer divergências são táticas ou apenas [referentes] ao grau [de implementação]. (ROTHBARD, 2016, p.159)

E a única forma de "salvar a liberdade desta fusão centrista entre esquerda / direita" seria por meio de uma "contra-fusão da Velha Direita [libertária] com a Nova esquerda" (ROTHBARD, 2016, p.160)

Destarte todos os esforços de Rothbard e seus aliados, outros fatores de ordem conjuntural dos anos 60 confluíram para que esquerda e direita a trabalhassem juntos. As mudanças nos hábitos e no estilo de vida decorrentes das traformações culturais causadas pela contracultura, também auxiliaram a diluir as diferenças entre direita e esquerda. Como afirma historiadora Rebecca Klatch, "Para os [ativistas] libertários na $\mathrm{YAF}^{18}$ a contracultura ofereceu meios para [que estes] reformula[ssem] suas crenças, provocando [uma] radicalização que [os levaram] forjar novos laços com os seus pares da esquerda." (KLATCH, 1999, loc.1856) ${ }^{19}$ Segundo Klatch, o consumo de drogas, como forma de expressar a liberdade pessoal e resistência a um poder centralizado, somada a repressão estatal decorrente do uso de tais substancias ilícitas, foram traços da contracultura que auxiliaram na aproximação entre os membros da Nova Esquerda e os libertários que abraçaram a cultura jovem de sua época (KLATCH, 1999, loc.2129). Até porque, muitos tradicionalistas repudivam o estilo de vida da contracultura "a partir de um ponto de vista religioso, acreditando que esta seria imoral" (KLATCH, 1999, loc.2013), o que, de acordo com a autora, teria contribuido para que os libertarios se distaciassem da Nova Direita e se aliassem com a SDS.

\section{Conclusão}

Diante do que foi exposto, pode-se perceber os váriados esforços efetivados pelos libertários na sua tentativa de converter a Nova Esquerda a uma posição de desprezo em relação a qualquer forma de intervencionismo estatal, ao mesmo tempo em que buscavam convencer outros libertários que haviam se juntado ao conservadorismo esboçado pela National Review a romperem com este, e se aliarem com os novos esquerdistas para assim consolidar sua alinça entre o libertarisnismo isolaiconista e o novo esquerdismo. Deve-se também ressaltar o fato desta aliança (ou pelo menos a tentativa de forjá-la) ter sido o resultado de transformações políticas ocorridas tanto na direita quanto na esquerda desde o pós-guerra. Como este trabalho tentou demonstrar crise política do laissez-faire para qual a Grande Depressão serviu de marco simbólico, foi o evento que possibilitou a reorganização das forças políticas dentro dos EUA.

Naquele momento, as forças de direita foram pegas de surpresa pela crise. Impactadas pelo baque gerado por esta, suas tentativas de lidar com o momento se limitaram a respostas dispersas e desorganizadas, enfatizando o livre-mercado, reafirmando a liberdade de atuação do indivíduo, denunciando o crescimento da interferência estatal, e pregando o isolacionismo em decorrência da Segunda Guerra Mundial. Isso abriu espaço para que a esquerda reformista protagonizasse uma resposta alternativa para aquele período de crise. O Partido Democrata sob a liderança de Roosevelt

\footnotetext{
18 A Young Americans for Freedom (YAF) era principal organização estudantil da Nova Direita, relacionada diretamente a William Buckley. Agrupava tradicionalistas e grande parte dos libertários que haviam seguido a linha editorial da National Review.

19 Neste trabalho utilizou-se a versão Kindle da obra de Klatch. O livro está referenciado nas citações bibliográficas ao final do texto
} 
apresentou então à sociedade americana o New Deal, que por meio de uma maior intervenção do Estado dentro da economia, propunha corrigir os excessos causados pelo laissez-faire.

A grande eficácia da proposta rooseveltiana em lidar com a Depressão serviu para que a América reorganizasse suas relações sociais no pós-guerra tendo como base o arcabouço institucional e a economia política desenvolvida durante os anos 30. No entanto, tal sucesso também abriu margem para transformação e rearticulação da direita ao longo do pós-45. Esta agora havia conseguido se reorganizar e articular suas críticas que antes estavam dispersas, focando no Estado de Bem-Estar Social no âmbito doméstico e no anticomunismo na política externa. Contudo, a reestruturação da direita não se viu livre de conflitos nem divisões, logo, a retórica conservadora que tinha como inimigo número um a URSS, gerou uma cisão no movimento. Assim, parte da direita libertária se viu inclinada a romper com o novo conservadorismo e buscar uma aliança com a esquerda, que também passou por modificações ao longo do pós-45.

Da mesma forma que o novo liberalismo americano afetou a direita, este também se refletiu na esquerda. Como afirma o historiador Paul Lyons (1996, p.5), o liberalismo americano do pósguerra "baseava-se no pressuposto, ancorado na teoria da modernização, de que as questões econômicas haviam sido resolvidas; que tudo o que restava era apenas realizar pequenos ajustes técnicos" A Nova Esquerda veio para dizer que os reparos a serem realizados não eram tão breves assim, já que tanto os problemas de natureza econômica quanto os de cunho político ainda permaneciam nos EUA, suprimindo totalmente da prosperidade trazida pelo Estado de Bem-Estar Social, grupos humanos inteiros, como no caso da população negra, e excluindo parcialmente pessoas pobres brancas.

Tais fatores, somados a atmosfera marcada pelo radicalismo, pela contracultura, pela ênfase na autonomia individual, e pela oposição à guerra do Vietnã que caracterizou os anos 60, auxiliaram na convergência entre segmentos da direita e parte da esquerda. Levando ambos os grupos a encontrar em suas respectivas retóricas, pontos coincidentes o suficiente para justificar uma aliança entre a facção do conservadorismo portadora do libertarianismo isolacionista, com a Nova Esquerda. Dentre as multiplas táticas esboçadas por estes para alcançar seus objetivos estavam o revisionismo histórico, tal qual fora apresentado no primeiro artigo da revista Left and Right, além da apropriação de determinados conceitos do novo esquerdismo, como o de democracia participativa, para tentar criar ou imprimir nesta a defesa ou adoção de uma visão de sociedade baseada no livre mercado irrestrito.

Entretanto, por mais que tais grupos tivessem meios e argumentações parecidas para atingir seus fins, os respectivos objetivos finais de libertários e novos esquerdistas diferiam significativamente. Os primeiros queriam resgatar, e se possível aprofundar, os princípios de uma sociedade ancorada no laissez-faire, pregando a total liberdade para o indivíduo, supremacia da ordem de mercado e limitação do tamanho e da atuação governamental como forma de solucionar possíveis distorções sociais (os mais radicais expoentes desta perspectiva defenderiam até mesmo o fim do Estado), mas sem necessariamente se importar com as desigualdades de natureza econômica ou política gerada por esse sistema. Já os últimos também acreditavam numa sociedade na qual liberdade pessoal fosse uma variável indispensável, contudo, seu objetivo final era criar uma comunidade em que igualdade material e ampla participação política dos indivíduos fossem os pilares essenciais. E embora acreditassem que para atingir tal fim, a desburocratização do aparelho estatal e a coibição de práticas autoritárias e discriminatórias por parte do governo, fossem pressupostos fundamentais isso não significava, inevitavelmente, o repúdio de qualquer e todo tipo de interferência estatal. Além de manterem certas reservas quanto ao papel do mercado irrestrito na 
promoção da equidade social.

A revista Left and Right deixou de ser publicada no ano de 1968 por causa de questões financeiras. Devido a isso, Rothbard inicia um outro veículo de mídia para continuar (pelo menos num primeiro momento) sua empreitada em consolidar uma aliança com a Nova Esquerda, e em 1969 surge o novo periódico chamado de Libertarian Forum (DOHERTY, 2009, p.345). Este viria ser o principal veículo opinião do libertarianismo, atravessando toda a década de 70 até o ano de 1984, momento em que este encerra suas atividades. Uma análise de sua linha editorial, seus principais artigos, e de que forma a revista viu os principais eventos dos anos 70, obviamente ultrapassa o escopo deste trabalho. No entanto, cabe apenas mencionar que nele a aliança entre libertarianismo e Nova Esquerda terá o seu desfecho final. Nesta publicação Rothbard cobrirá o esfacelamento da SDS no final da convenção nacional de 1969, a expulsão dos libertários da YAF também no ano de 1969, além de expor as razões do porquê os libertários devem se dissociar do novo esquerdismo e iniciar um movimento independente tanto da National Review quanto da Nova Esquerda.

\section{Fontes}

BUCKLEY, William, Our Mission Statement disponivel em: https://www.nationalreview.com/1955/11/our-mission-statement-william-f-buckley-jr/. Acesso em: 27 de abr. 2019

"Three Drafts of an Answer to Mr. Hamowy," New Individualist Review 1, no. 3 (November 1961) Acesso em: 27 de abr. 2019

BYNERS, Jesse. Libertarian nominee: I agree with 73 percent of what Sanders says. disponivel em: 2019 https://thehill.com/blogs/ballot-box/presidential-races/281765-libertarian-nominee-iagree-with-most-of-what-sanders-says Acesso em: 04 Jun. 2019

CHAMBERLIN, William. Crisis of American Foreign Police Faith and freedom, September 1954, disponivel em: https://mises-media.s3.amazonaws.com/FAF54-9_3.pdf p.12 Acesso em: 25 de abr. 2019

CHODOROV, Frank A war to Comunize América. The Freeman November 1954. disponivel em: https://fee.org/media/16482/1954-11.pdf Acesso em: 25 de abr. 2019

CHODORV, Frank. the return to 1940? The Freeman, September 1954 disponivel em: https://fee.org/media/16484/1954-9.pdf Acesso em: 25 de abr. 2019

HAMOWY, Ronald “'National Review': Criticism and Reply," New Individualist Review 1, no. 3 (November 1961) Acesso em:27 de abr. 2019

HEBERT, Aubrey, [Murray Rothbard]. The real agressor Faith and Freedom Abril 1954. Disponivel em: https://mises-media.s3.amazonaws.com/FAF54-4_3.pdf Acesso em: 25 de abr. 2019

Left and Right: A Journal of the libertarian thought disponivel em: https://mises-media.s3.amazonaws.com/Left\%20and\%20Right\%20A\%20Journal\%20of\%20Liberta-

rian\%20Thought\%20\%28Complete\%2C\%201965-1968\%29_2.pdf

MEYER, Frank, the twisted tree of liberty disponivel em: https://www.nationalreview.com/2017/01/communism-conservatism-twisted-tree-liberty/ Acesso em: 28 de abr. 2019

ROTHBARD, Murray "Confessions of a Right-Wing Liberal," Ramparts, June 15, 1968 in RAIMONDO, Justin (org). Never a Dull Movement: A libertarian look at the sixties. Mises Institue. Auburn, 2016

. Esquerda e direita Perspectivas para a liberdade. Instituto Ludwig von Mises Brasil, São Paulo, 2010, disponível em: www.mises.org.br/files/literature/esquerda\%20e\%20direita.pdf Acesso em: 28 de abr. 2019 
. Liberty and the New Left. Left and Right: A Journal of the Libertarian Thought Vol. I, No.2

Autumm 1965

"SDS: The New Turn" Left and Right: A Journal of the Libertarian Thought Vol. III, No. 1 (Winter 1967) p.368

The betrayal of the American Right. Ludwig von Mises Institute. Auburn. 2007 Disponivel em:mises.org/document/3316/The-Betrayal-of-the-American-Right

SCHLAMM, William. But is not 1940, The Freeman, September 1954 disponível em: https://fee.org/media/16484/1954-9.pdf Acesso em: 25 de abr. 2019

\section{Referências}

BJERRE-POULSEN, Standing Athwart History, Yelling Stop: The Emergence of American Movement Conservatism, 1945-1965 American Studies in Scandinavia, 45:1-2

BURGIN, Angus. The Great Persuasion: Reinventing Free Markets since the Depression. Cambridge, MA, Harvard University Press, 2012

DOHERTY, Brian. Radicals for capitalism: a freewheeling history of the modern American libertarian movement. Public Affairs, 2009.

HOBSBAWM, Eric. A Era dos Extremos: o breve século XX 1914-1991. SP: Cia. Das Letras, 1995.

KELLEY, Jonh L. Bringing the Market Back in The Political: Revitalization of Market Liberalism. Macmillian press LTD Hampshire, 1997.

KLATCH, Rebecca E. A Generation Divided: The New Left, the New Right, and the 1960s. University of California Press, Berkeley. 1999.

LIMONCIC, Flávio. Os inventores do New Deal: Estado e sindicatos no combate à Grande Depressão. Rio de Janeiro: Civilização Brasileira, 2009

LYONS, Paul. New Left, New Right, and the Legacy of the Sixties. Temple University Press, New York: 1996

NASH, George H. The Conservative Intellectual Movement in America since 1945. ISI Books, Wilmington: 2006

PAYNE, John. Rothbard's time on the left. Journal of libertarian Studies Volume 19. NO. 1 (Winter 2005): 7-25.

RAIMONDO, Justin Reclaiming the American Right: the lost legacy of the conservative movement. Wilmington, Delaware: Intercollegiate Studies Institute, 2008.

ROBERT, Frédéric The New Left in the Sixties: Political Philosophy or Philosophical Politics? American International Journal of Contemporary Research Vol. 6, No. 4; August 2016

SKAGGS, Jonathan. The Old Right and its influence on the development of modern american conservatism. 2014. 228 f. Tese (Doutorado em História)- Faculty of the Graduate College of the Oklahoma State University

SOUSA, Rodrigo Farias de. A Nova Esquerda americana: de Port Huron aos Weathermen 19601969. Rio de Janeiro: FGV, 2009.

. William F. Buckley Jr., National Review e a crítica conservadora ao liberalismo e os direitos civis nos EUA, 1955-1968.2013. Tese (Doutorado em história) - Instituto de Ciências Humanas e Filosofia, Universidade Federal Fluminense, Niterói, 2013.

Artigo recebido em: 19/10/2019

Artigo aceito em: 20/12/2019 